Original Research Paper

\title{
Growth Performance Sargassum sp. Cultivated in Labuan Ijuk, Moyo Hilir Sumbawa Besar Regency, Nusa Tenggara Barat
}

\author{
Nunik Cokrowati $^{1 *}$, Dewi Nur'aeni Setyowati ${ }^{1}$, Salnida Yuniarti Lumbessy ${ }^{1}$, \\ Erwansyah $^{2}$ \\ ${ }^{1}$ Program Studi Budidaya Perairan, Jurusan Perikanan dan Ilmu Kelautan, Fakultas Pertanian, \\ Universitas Mataram, Mataram, Indonesia. \\ ${ }^{2}$ Program Studi Teknik Pertambangan, Fakultas Teknik, Universitas Cordova Sumbawa Barat, \\ Taliwang, Indonesia.
}

\author{
Article History \\ Received : August $13^{\text {th }}, 2021$ \\ Revised : August $30^{\text {th }}, 2021$ \\ Accepted : September $11^{\text {th }}, 2021$ \\ Published : September $21^{\text {th }}, 2021$ \\ *Corresponding Author: \\ Nunik Cokrowati, \\ Program Studi Budidaya Perairan, \\ Jurusan Perikanan dan Ilmu \\ Kelautan, Fakultas Pertanian, \\ Universitas Mataam. \\ Email: \\ nunikcokrowati@unram.ac.,id
}

\begin{abstract}
Sargassum sp. is an alginate-producing brown alga that is used in the food, drug, and cosmetic industries. Sargassum sp. can be found in the waters of West Nusa Tenggara, namely on the islands of Lombok and Sumbawa. Sargassum sp. has not been cultivated in the waters of West Nusa Tenggaracurrently, Sargassum sp. is only exploited from nature. So it is necessary to cultivate efforts in the waters of West Nusa Tenggara. The waters of Labuan Ijuk, Sumbawa Besar Regency, have the potential as a location for the development of Sargassum sp. This study aimed to study the growth performance of Sargassum sp. with different initial seedling weights by using the bottom-off method. The research method used is the experimental method with the experimental design is a completely randomized design. The treatment in this study consisted of five treatments with four replications. Treatment A with 50 gr seed weight, B 75 gr seed weight, C 100 gr seedling weight, D $125 \mathrm{gr}$ seedling weight, and E 150 gr seedling weight. Data analysis using ANOVA and 5\% BNJ follow-up test. The results showed that the highest absolute weight was obtained in treatment E, which was $39.75 \mathrm{~g}$, as well as the highest specific weight was obtained in treatment $\mathrm{E}$, which was $36.81 \%$. The lowest absolute weight was obtained in treatment C, 24.25 $\mathrm{g}$, with the lowest specific weight also being $26.47 \%$. This research concludes the optimum growth of Sargassum sp. obtained in cultivation using an initial seed weight of $150 \mathrm{gs}$.
\end{abstract}

Keywords: Seaweed, aquaculture, alginate, weight, industry.

\section{Pendahuluan}

Sargassum sp. merupakan alga coklat dan hidup di perairan laut tropis dan juga pada perairan laut sub tropis. Sargassum Sp. dapat dijumpai di perairan Indonesia diantaranya adalah di perairan laut Pulau Lombok, Sumbawa, Bali, Karimun Jawa, Madura, Ambon, Kalimantan dan Sulawesi. Sargassum sp. belum dibudidayakan karena jumlahnya dianggap melimpah oleh masyarakat dan nilai ekonominya tidak setinggi nilai ekonomi alga merah dan alga hijau. Masyarakat selama ini memanfaatkan sebagai obat penyakit gondok, gangguan kalenjar, gatal-gatal dan gangguan saluran kencing (Firdaus, 2013). Sidauruk et al., (2021) menjelaskan bahwa Sargassum plagyphylum jika diambil ekstraknya dapat digunakan sebagai antibakteri dari kandungan senyawa bioaktifnya yaitu fenolik, steroid, alkaloid dan saponin. Kordi (2010); Guedes et al., (2012) menyebutkan bahwa rumput laut coklat memiliki potensi senyawa bioaktif yang dapat digunakan sebagai anti tumor, antibakteri, anti kanker dan anti septik. Bahtiar (2007) pada penelitainnya menggunakan rumput laut coklat sebagai fungisida dan herbisida. Nurjanah et al., (2019) menggunakan Sargassum dan rumput laut sebagai bahan kosmetik pelindung kulit dari sinar matahari. 
Sargassum sp. merupakan alga coklat penghasil alginat yang digunakan pada industri makanan, obat, dan kosmetik. Sargassum sp. dapat di jumpai di perairan Nusa Tenggara Barat yaitu di pulau Lombok dan Pulau Sumbawa. Sargassum sp. di perairan Pulau Sumbawa dapat diperoleh di perairan Kertasari Sumbawa Barat, Moyo Hilir Sumbawa, Teluk Saleh, Dompu dan Bima. Sargassum sp. hidup menempel pada subtrat dasar perairan pada kedalaman $1 \mathrm{~m}$ sampai dengan $5 \mathrm{~m}$. Sargassum sp. saat ini di perairan pulau Sumbawa di ambil bebas dari perairan umum dan dijual dalam bentuk kering. Sargassum sp. dijual sebagai bahan baku kertas pembungkus makanan yang diproduksi di industri Surabaya. Sargassum sp. di Sumbawa belum dibudidayakan dan teknologi budiayanya belum diketahui oleh masyarakat. Wila et al., (2021) melakukan budidaya Sargassum aquifolium pada kedalaman tanam yang berbeda menggunakan metode rawai, meghasilkan pertumbuhan dan rendemen alginat yang berbeda. Fajri (2020) mendapatkan hasil pertumbuhan yang berbeda dari Sargassum yang dibudidayakan pada jarak tanam yang berbeda menggunakan rakit apung. Sulistyaningsih et al., (2019) mengkombinasikan budidaya Sargassum aquifoliun dan Kappaphycus alvarezii untuk mengetahui pengaruh keduanya terhadap serangan penyakit ice-ice.

Perairan Moyo Hilir terletak di pulai Sumbawa, memiliki sumberdaya perikanan diantaranya ikan, rumput laut dan Sargassum sp. Perairan Moyo Hilir memiliki kualitas air yang baik dan jernih sehingga mendukung untuk kebhidupan biodiversitas yang ada di dalamnya (Saraswati et al., 2017). Saat ini di perairan tersebut hanya berlangsung aktifitas penangkapan ikan dan belum ada kegiatan budidaya. Alga coklat ini dapat dijumpai di perairan Moyo Hilir pada kedalaman kurang lebih 1 meter dan melekat kuat pada subtrat dasar perairan. Sargassum sp di perairan Moyo Hilir belum dimanfaatkan oleh masyarakat. Jika Sargassum sp saat ini mulai diminati sebagai komoditas ekspor dan jika diambil terus menerus dari alam maka akan berpotensi punah. Sehingga diperlukan penelitian teknologi budidaya Sargassum sp. untuk keberlanjutan sumberdaya tersebut. Penelitian ini bertujuan untuk mengetahui performa pertumbuhan Sargassum sp. yang dibudidayakan dengan menggunakan berat bibit awal yang berbeda.

\section{Bahan dan Metode}

Penelitian dilaksanakan pada bulan November 2020 sampai dengan Januari 2021 di Pantai Arang Desa Labuhan Ijuk Kecamatan Moyo Hilir Kabupaten Sumbawa Besar. Bahan dan alat yang digunakan untuk budidaya adalah patok bambu, Sargassum sp., tali rafia, tali nilon, tagging plastik, kamera, timbangan, refraktometer, $\mathrm{pH}$ meter, stopwatch, meteran dan botol plastik.

Metode penelitian yang digunakan adalah metode eksprimental dengan rancangan acak lengkap (RAL) dengan 4 perlakuan dan 4 ulangan terhadap perbedaan jarak tanam dengan metode patok dasar yang dilakukan selama 30 hari. Perlakuan tersebut yaitu bibit Sargassum sp. ditanam dengan berat bibit $50 \mathrm{~g}$ (A), $75 \mathrm{~g}$ (B), 100 $\mathrm{g}(\mathrm{C})$, dan $125 \mathrm{~g}(\mathrm{D})$ dan $150 \mathrm{~g}(\mathrm{E})$. Ulangan yang digunakan adalah jumlah tali ris. Jarak antar tali ris adalah $30 \mathrm{~cm}$. Patok ditancapkan pada subtrat dasar perairan dengan jarak $5 \mathrm{~m}$ untuk patok tali utama dan untuk tali ris berjarak $30 \mathrm{~cm}$. Jarak patok yang berhadapan adalah $5 \mathrm{~m}$, maka tali ris yang dipersiapkan dengan panjang $7 \mathrm{~m}$.

Variabel penelitian yang diukur adalah pertumbuhan mutlak, pertumbuhan spesifik dan kualitas air. Pertumbuhan mutlak dihitung dengan menggunakan rumus Sahabati et al., (2016):

Keterangan:

$$
\Delta W=W t-W o
$$

$\Delta W:$ Pertumbuhan Mutlak (g)

$W t$ : Berat rata-rata rumput laut pada akhir percobaan $(\mathrm{g})$

$W o$ : Berat rata-rata rumput laut pada awal percobaan $(\mathrm{g})$

Pertumbuhan spesifik dihitung dengan menggunakan rumus Kasim et al., (2017):

Keterangan:

$$
\mathrm{SGR}=\frac{\ln \mathrm{Wt}-\ln \mathrm{Wo}_{\mathrm{o}}}{t} \times 100 \%
$$

SGR : Laju Pertumbuhan Spesifik (\% dalam berat basah per hari)
Wt : Berat bobot setelah sehari
Wo : Berat bobot awal
$\mathrm{t} \quad$ : Waktu dalam hari 


\section{Hasil dan Pembahasan}

Pertumbuhan mutlak
Pertumbuhan mutlak Sargassum sp. pada penelitian ini sebagaimana pada gambar berikut ini.

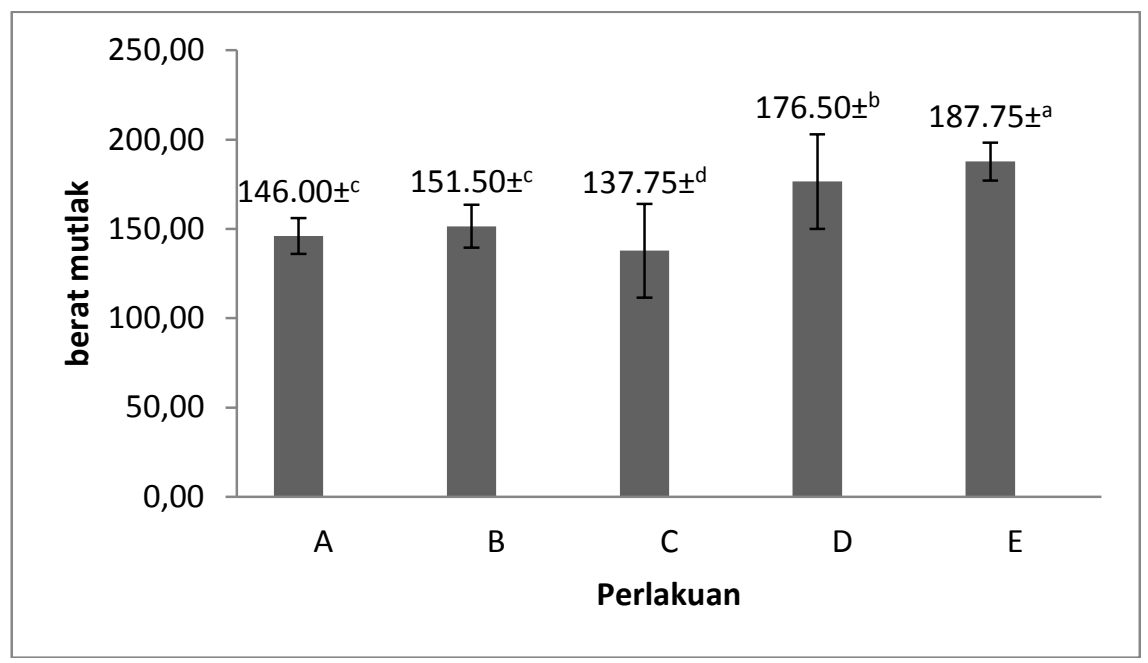

Gambar 1. Pertumbuhan mutlak Sargassum sp. yang dibudidayakan

Pertumbuhan mutlak paling tinggi adalah perlakuan E yaitu berat bibit awal $150 \mathrm{~g}$ sebesar 187,75 g. Pertumbuhan mutlak terendah terjadi pada perlakuan $\mathrm{C}$ yaitu berat bibit awal $100 \mathrm{~g}$. Berdasarkan uji lanjut ANOVA menyatakan bahwa setiap perlakuan pada penelitian ini menunjukkan perbedaan nyata. Jika diurutkan maka dari pertumbuhan yang paling tinggi adalah bibit $150 \mathrm{~g}$ (perlakuan E), bibit $125 \mathrm{~g}$ (perlakuan D), bibit $75 \mathrm{~g}$ (perlakuan B), bibit 50 g (perlakuan A) dan bibit $100 \mathrm{~g}$ (perlakuan C). Pada umumnya, budidaya rumput laut untuk jenis Kappaphycus alvarezii menggunakan berat bibit $100 \mathrm{~g}$ dan dapat menghasilkan pertumbuhan optimal serta memberikan keuntungan secara ekonomis. Budidaya Sargassum sp belum pernah dilakukan sehingga perlu diuji berbagai berat bibit yang dapat mengasilkan pertumbuhan maksimal dan menghasilkan keuntungan ekonomi yang maksimal juga.

\section{Pertumbuhan spesifik}

Pertumbuhan spesifik Sargassum sp dapat menggambarkan berapa laju pertumbuhan per waktu pada Sargassum sp yang dibudidayakan. Berikut adalah pertumbuhan spesifik pada penelitian ini.

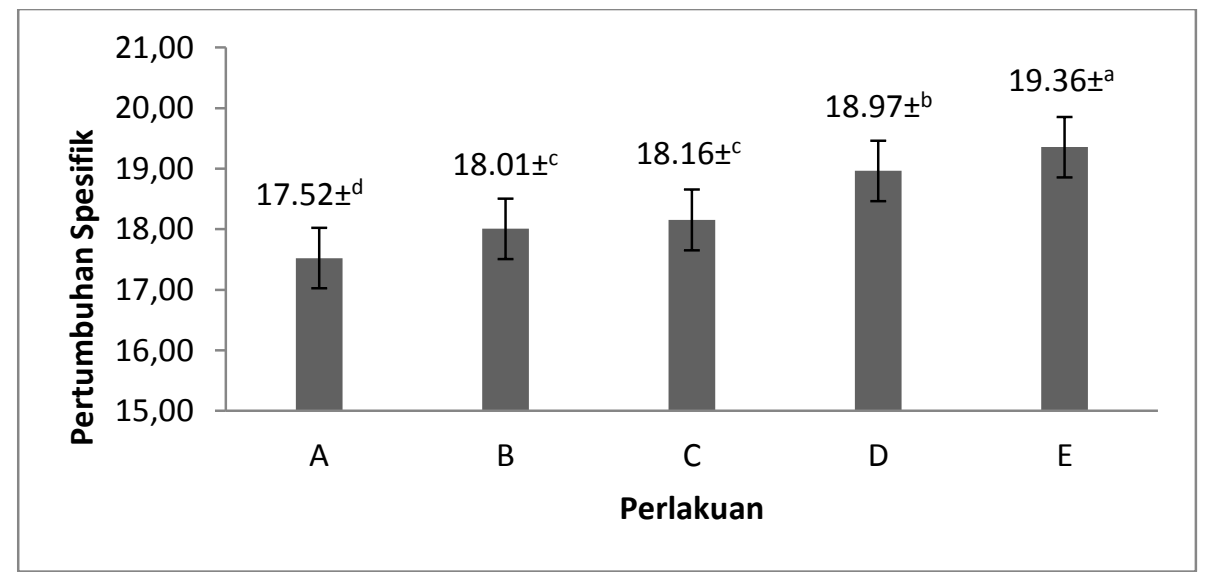

Gambar 2. Pertumbuhan spesifik Sargassum sp. yang dibudidayakan 
Pertumbuhan spesifik merupakan gambaran dari pertambahan berat per hari yang dialami oleh Sargassum sp. Dengan demikian akan dapat diketahui pada hari ke berapa pertumbuhan terjadi maksimal dan kapan pertumbuhan mulai melamban. Pertumbuhan spesifik juga dapat digunakan sebagai dasar berapa waktu yang dibutuhkan untuk budidaya Sargassum sp. sampai dengan panen. Pada penelitian ini pertumbuhan spesifik tertinggi di alami oleh Sargassum sp. yang dibudidayakan dengan berat bibit awal $150 \mathrm{~g}$ (perlakuan E). Pertumbuhan spesifik terendah dialami oleh Sargassum sp. dengan berat bibit awal $50 \mathrm{~g}$ (perlakuan A). Pertumbuhan spesifik setiap perlakuan berdasarkan hasil uji lanjut ANOVA, memiliki perbedaan nyata antar perlakuan. Sehingga pada aplikasi budidayanya dapat dipertimbangkan untuk mendapatkan pertumbuhan yang maksimal dan waktu budidaya yang minimal.

\section{Kualitas Air}

Perairan Moyo Hilir dikenal memiliki keindahan pantai yang memiliki nilai estetika dan jernih. Kondisi subtart darar perairan sebagain besar adalah terumbu karang dan pasir putih. Pada perairan ini tidak banyak aktivitas kegiatan manusia sehingga perairan relatif bersih. Berikut adalah nilai parameter kualitas air pada lokasi budidaya Sargassum sp.

Tabel 2. Kualitas Air Selama Penelitian

\begin{tabular}{lll}
\hline Parameter & Nilai & Referensi \\
\hline Suhu $\left({ }^{\circ} \mathrm{C}\right)$ & $28-30$ & $26-32($ BSN, 2011) \\
pH & $7,6-8,0$ & $6,5-8,0$ (Ichwanul, 2020) \\
Oksigen terlarut $(\mathrm{ppm})$ & $7,1-7,3$ & $3-8$ (Muslimin, 2017) \\
Kedalaman $(\mathrm{m})$ & $0,50-1,10$ & $0,5-10$ (Muslimin, 2017) \\
Kecepatan Arus $(\mathrm{cm} / \mathrm{s})$ & $20,90-23,16$ & $20-40$ (Yusup, 2015) \\
Salinitas (ppt) & $30-31$ & $32-33,5$ (Ichwanul, 2020) \\
\hline
\end{tabular}

Berdasarkan nilai parameter kualitas air pada tabel diatas, perairan Labuan Ijuk dapat dijadikan lokasi budidaya Sargassum sp. Namun harus disesuaikan dengan zonasi pemanfaatan ruang laut yang telah ditetapkan oleh pemerintah setempat. Jika ada alokasi ruang laut untuk budidaya maka dapat disosialisasikan ke masyarakat untuk budidaya Sargassum sp dengan teknologi sederhana berdaasarkan hasil penelitian ini.

\section{Pertumbuhan mutlak}

Pertumbuhan mutlak selisih berat keseluruhan Sargassum sp dari awal penanaman sampai dengan panen. Pada penelitian ini Sargassum sp dibudidayakan selama 30 hari dengan menggunakan metode patok dasar. Pertumbuhan mutlak tertinggi pada penelitian ini adalah Sargassum sp. yang dibudidayakan dengan berat bibit yang paling banyak yaitu 150 g. Pada penelitian ini pertumbuhan mutlak tertinggi tersebut terjadi karena berat bibit $150 \mathrm{~g}$ lebih mampu melawan gerakan air dibanding berat bibit yang lebih rendah. Sehingga energi yang dimiliki oleh Sargassum sp dengan berat bibit $150 \mathrm{~g}$ tersebut lebih banyak digunakan untuk pertumbuhan. Sedangkan semakin kecil berat bibit yang digunakan maka energi yang dimiliki lebih banyak digunakan untuk melawan gerakan air. Mengingat budidaya Sargassum sp. ini dilakukan di area pantai sehingga gerakan air relatif lebih besar. Berat bibit $150 \mathrm{~g}$ dapat menghasilkan berat mutlak maksimal dapat diartikan bahwa berat tersebut masih dalam kapasitas Sargassum sp untuk dapat tumbuh secara maksimal dengan dukungan kualitas perairan dan nutrien yang ada di perairan Labuan Ijuk. Penelitian Afifilah et al., (2021) menjelaskan bahwa berat bibit Sargassum sp 200 g yang di budidayakan di Teluk Ekas Lombok dapat menghasilkan pertumbuhan mutlak optimal dengan waktu pemeliharaan selama 30 hari.

Eismaputri et al., (2013) menjelaskan hasil penelitiannya bahwa pertumbuhan mutlak Sargassum sp. yang dibudidayakan lebih dipengaruhi oleh kondisi biofisik perairan diantaranya suhu dan salinitas perairan. 
Muslimin (2017) menjelaskan hasil penelitiannya bahwa pertumbuhan Sargassum sp. dipengaruhi oleh intensitas cahaya. Dengan demikian budidaya Sargassum sp. perlu memperhatikan faktor kedalaman perairan yang berhubungan dengan intensitas cahaya matahari. Arjuni et al., (2018) menjelaskan hasil penelitiannya bahwa posisi tanam rumput laut dan berat bibit yang digunakan memberikan pengaruh terhadap pertumbuhan mutlak. Posisi tanam yang dimaksud adalah pada kolom kedalaman perairan yang digunakan. Damayanti et al., (2019) juga menjelaskan bahwa rumput laut yang dibudidayakan pada kolom permukaan air dapat menghasilkan pertumbuhan mutlak yang lebih tinggi.

\section{Pertumbuhan spesifik}

Pertumbuhan spesifik merupakan pertambahan berat Sargassum sp per hari selama periode budidaya yang dilakukan. Pertumbuhan spesifik tertinggi pada penelitian ini adalah pada perlakuakn $\mathrm{E}$ yaitu dengan berat bibit $150 \mathrm{~g}$ yaitu $19,36 \%$ per hari. Berat bibit awal $150 \mathrm{~g}$ masih dalam kapasitas padat tebar yang mampu menyerap nutrien secara maksimal sehingga pertumbuhan spesifik dapat terjadi maksimal. Jarak ikatan antar tali ris pada penelitian ini adalah $30 \mathrm{~cm}$ sehingga Sargassum sp. masih dapat memperoleh ruang yang cukup untuk menyerap nutrien dan tidak terjadi kemungkinan perebutan nutrien. Penelitian Fajri et al., (2020) menjelaskan hasil bahwa ini pertumbuhan spesifik terbaik Sargassum sp dibudidayakan dengan jarak tanam $33 \mathrm{~cm}$.

Hasil penelitian menunjukan bahwa berat bibit yang berbeda mempengaruhi laju pertumbuhan spesifik rumput laut Sargassum $s p$. Hasil ini dibuktikan dengan analisis rata-rata laju pertumbuhan spesifik pada setiap perlakuan. Menurut Rochmady (2015), pertumbuhan rumput laut didukung oleh kecukupan unsur hara dalam perairan serta faktor fisik perairan berupa suhu dan intensitas cahaya matahari. Pada perairan Labuan Ijuk, faktor tersebut berada pada kisaran yang dapat mendukung pertumbuhan Sargassum sp. Sehingga setiap perlakuan mengalami laju pertumbuhan yang rata-rata mengalami peningkatan sesuai berat bibit yang digunakan.

Pertumbuhan spesifik pada hasil penelitian ini juga dipengaruhi oleh metode budidaya yang digunakan yaitu metode patok dasar yang memungkinkan Sargassum sp. memperoleh cahaya matahari secara maksimal. Lutfiawan et al., (2015) menjelaskan hasil penelitiannya nahwa Sargassum sp yang dibudidayakan dengan menggunakan metode patok dasar mengalami pertumbuhan yang lebih cepat dibanding dengan menggunakan metode rakit apung dan longline. Pada metode patok dasar Sargassum sp. lebih banyak mendapatkan sinar matahari dikarenakan kedalam yang lebih rendah dibandingkan dengan menggunakan metode lainnya. Runtuboy et al., (2018) menjelaskan hasil penelitiannya bahwa pada kedalaman efektif penetrasi sinar matahari permukaan tercatat presentasi laju pertumbuhan harian terbaik rumput laut yaitu 7,77-10,85\%. Penetrasi sinar matahari yang semakin berkurang pada media pertumbuhan bibit maka semakin kecil presentasi laju pertumbuhan harian.

Laju pertumbuhan spesifik juga dipengaruhi oleh kualitas bibit yang digunakan. Bibit Sargassum sp yang digunakan pada penelitian ini diambil dari bibit yang dihidup secara alami di perairan Labuan Ijuk. Bibit yang digunakan dapat dikategorikan memiliki kualitas yang baik dengan ciri keseluruhan bagian tanaman dalam kondisi segar dengan warna coklat sebagaimana warna aslinya. Kotta (2020) menjelaskan hasil penelitiannya bahwa ciri bibit yang berkualitas adalah segar, elastis, tidak ditempeli biota lain dan berwarna coklat sebagaimana warna aslinya. Penggunaan metode budidaya juga dapat mempengaruhi kualitas bibit rumput laut yang dihasilkan.

\section{Kualitas air}

Hasil pengukuran suhu yang didapatkan dilokasi penelitian berkisar antara $28-30^{\circ} \mathrm{C}$. Suhu perairan terhadap kecepatan fotosintesis terkait dengan pola kerja enzim. Suhu perairan yang terlalu rendah atau terlalu tinggi menyebabkan pertumbuhan yang kurang baik bagi Sargassum sp. Muslimin (2017) menjelaskan bahwa suhu yang terlalu rendah maupun terlalu tinggi menyebabkan pertumbuhan kurang optimal akibat kerja enzim yang berperan sebagai katalisator proses fotosintesis tidak dapat bekerja dengan baik pada suhu yang terlalu rendah maupun terlalu tinggi. Yudasmara (2014) menjelaskan bahwa suhu perairan yang optimum untuk pertumbuhan rumput laut adalah $27,5^{\circ} \mathrm{C}$. 
Nilai oksigen terlarut dilokasi penelitian berkisar antara 7,1-7,3 ppm, nilai tersebut menunjukkan bahwa kondisi perairan baik untuk pertumbuhan Sargassum sp. Menurut Ichwanul (2020) menjelaskan bahwa oksigen terlarut yang optimal untuk pertumbuhan Sargassum sp. berkisar antara 3-8 ppm. Sargassum sp. membutuhkan lebih banyak oksigen ketika kondisi tidak ada intensitas cahaya yang cukup.

Kedalaman perairan sangat berkaitan dengan suhu perairan yang dipengaruhi oleh pasang surut air laut. Kedalaman kolom perairan pada lokasi penelitian berkisar dari 0,50-1,10 meter. Muslimin (2017), menjelaskan kelayakan nilai kedalaman budidaya Sargassum sp. berkisar antara 0,50-10 meter. Nilai kedalaman perairan mempengaruhi nilai kecerahan yang dipengaruhi oleh keadaan cuaca,waktu pengukuran, kekeruhan, dan padatan tersuspensi. Pada perairan yang cerah, sinar matahari dapat optimal masuk ke dasar perairan. Sinar matahari diperlukan untuk melakukan proses fotosintesis untuk pertumbuhan. Hal ini diperkuat oleh pernyataan Insan dalam Sunu (2015), yang menjelaskan bahwa bahwa cahaya matahari dapat mencapai ke dasar perairan sehingga fotosintesis dapat berlangsung optimal.

Derajat keasaman atau $\mathrm{pH}$ dilokasi penelitian yaitu berkisar 7,6-8. $\mathrm{pH}$ perairan mempengaruhi toksisitas suatu perairan. Organisme akuatik sebagian besar sensitif terhadap perubahan $\mathrm{pH}$. Menurut Ichwanul (2020), nilai pH air yang sesuai untuk Sargassum sp.berkisar antara 6,9-8. pH perairan dipengaruhi oleh kapasitas penyangga (buffer) yaitu adanya garam-garam karbonat dan bikarbonat yang terkandung didalamnya. Salinitas perairan di lokasi penelitian yaitu berkisar antara 30-31 ppt. Kisaran salinitas yang terukur selama penelitian masih dalam kisaran yang dapat ditolerir sehingga dapat mendukung pertumbuhan Sargassum sp. Salinitas berperan penting dalam pertumbuhan Sargassum sp. apabila salinitas turun secara drastis, maka akan berakibat menurunnya kualitas Sargassum sp. Menurut Ichwanul (2020), salinitas yang sesuai untuk budidaya Sargassum sp. berada pada kisaran 32-33,5 ppt. BSN (2011) menjelaskan bahwa nilai salinitas untuk menunjang pertumbuhan rumput laut berkisar antara 28-34 ppt. Kecepatan Arus merupakan faktor penting dalam pertumbuhan Sargassum sp. Kecepatan arus berperan dalam transportasi unsur hara sebagai sumber makanan. Nilai kecepatan arus dilokasi penelitian yaitu $20,90-23,16 \mathrm{~cm} / \mathrm{s}$. Muslimin (2017) menjelaskan bahwa kecepatan arus yang optimal untuk pertumbuhan Sargassum sp. adalah berkisar $20-40 \mathrm{~cm} /$ detik. Kecepatan arus memiliki peran dalam membawa nutrisi yang dibutuhkan oleh Sargassum sp. dalam mencukupi nutrient serta unsur hara untuk pertumbuhan. Semakin baik sirkulasi perairan yang didukung oleh kecepatan arus maka pertumbuhan Sargassum sp. akan semakin cepat karena difusi nutrient kedalam sel tanaman semakin banyak sehingga metabolisme dipercepat. Jika gerakan air yang bagus maka akan membawa nutrien yang cukup dan dapat mencuci kotoran-kotoran halus dan substrat yang menempel pada talus. Novianti et al,. (2015) menjelaskan bahwa kecepatan arus yang baik untuk budidaya rumput laut sebesar $20-40 \mathrm{~cm} / \mathrm{s}$. Pertumbuhan Sargassum sp. seperti halnya biota perairan lainnya dipengaruhi oleh toleransi fisiologi dari biota tersebut untuk beradaptasi terhadap faktor-faktor lingkungan seperti substrat, suhu, salinitas, $\mathrm{pH}$ dan arus. Pertumbuhan Sargassum sp. terjadi karena Sargassum sp. melakukan proses respirasi dan fotosintesis.

\section{Kesimpulan}

Kesimpulan penelitian ini adalah pertumbuhan optimum Sargassum sp. pada penelitian ini dihasilkan oleh perlakuan berat bibit awal $150 \mathrm{~g}$ dengan pertumbuhan mutlak $187,75 \mathrm{~g}$ dan pertumbuhan spesifik $19,36 \%$ per hari.

\section{Ucapan terima kasih}

Ucapan terima kasih disampaikan kepada masyarakat dan aparat pemerintah Desa Labuan Ijuk yang telah mendukung terlaksananya penelitian ini.

\section{References}

Arjuni, Andy, Nunik, C. \& Rusman (2018). Pertumbuhan Rumput Laut Kappaphycus alvarezii Hasil Kultur Jaringan. Jurnal Bologi Tropis. 18 (2): 216-223. DOI: http://dx.doi.org/10.29303/jbt.v18i2.740. 
Afifilah, Ifla, Nunik, C. \& Nanda, D. (2021). The Weight of Seedlings Differs on the Growth of Sargassum sp. Jurnal Biologi Tropis. 21 (1): $288-297 . \quad$ DOI: http://dx.doi.org/10.29303/jbt.v21i1.2540.

Bachtiar A. (2007). Penelusuran Sumber Daya Hayati Laut (Alga) Sebagai Biotarget Industri. Makalah. Jatinangor (ID): Fakultas Perikanan dan Ilmu Kelautan Universitas Padjadjaran.

Badan Standar Nasional (BSN) (2011). Produksi Bibit Rumput Laut Kotoni (Eucheuma cottoni). Bagian 1 : Metode Lepas Dasar. Jakarta.

Damayanti, Tri., Riris, A. \& Fauziyah (2019). Laju Pertumbuhan Rumput Laut Eucheuma cottonii (Kappaphycus alvarezi) Dengan Bobot Bibit Awal Berbeda Menggunakan Metode Rakit Apung Dan Long Line Di Perairan Teluk Hurun Lampung. Maspari Journal. 11(1):17-22.

Eismaputeri, M.K., M. A. Alamsjah \& Boedi, S.R. (2013). Pengaruh Lama Penyinaran dan Salinitas Terhadap Pertumbuhan dan Jumlah Klorofil a Sargassum sp. Jurnal Ilmiah Perikanan dan Kelautan Vol. 5 No. 1. http://dx.doi.org/10.20473/jipk.v5i1.11 432.

Firdaus, M. (2013). Indeks Aktivitas Antioksidan Ekstrak Rumput Laut Coklat (Sargassum aquifolium). Antioxidant Activity Index of Brown Seaweed (Sargassum aquifolium) Extract. JPHPI. Vol. 16.

Fajri, M.I. (2020). Pengaruh Jarak Tanam Rumput Laut (Sargassum sp.) yang Berbeda Terhadap Pertumbuhan. Sains Akuakultur Tropis: Indonesian Journal of Tropical Aquaculture. 4(2), 156160. https://doi.org/10.14710/sat.v4i2 .6920 .
Guedes, C.A.E., Maria, A.S.A., Aryanna, S.P.K., Larissa, S.O.I., Lurdiana, B.D., Fernanda, M.A.C., \& Antonia, S.G.E. (2012). Antifungal Activities of Different Extracts of Marine Macroalgae Againts Dermatophytes and Candida Species. $\begin{array}{lll}\text { Mycopathologia. } 174 & \text { (3):223-232. }\end{array}$ DOI: $10.1007 / \mathrm{s} 11046-012-9541-\mathrm{Z}$

Ichwanul, M, F., I. Samidjan, \& D. Rachmawati (2020). Pengaruh Jarak Tanam Rumput Laut (Sargassum sp.) Yang Berbeda Terhadap Pertumbuhan. Jurnal Sains Akuakultul Tropis. 4(2).

Kordi, K. (2010). A to Z Budi Daya Biota Akuatik untuk Pangan, Kosmetik dan Obat-obatan. Yogyakarta (ID): Penerbit Andi.

Kasim, M., \& Ahmad, M. (2017). Comparison Growth Of Kappaphycus Alvarezii (Rhodophyta, Solieriaceae) Cultivation In Floating Cage And Longline In Indonesia. Jurnal Aquaculture Reports. 6 : 49-55. https://doi.org/10.1016/j.aqrep.2017.03.00 4.

Kotta, R. (2020). Pertumbuhan Rumput Laut Kappaphycus alvarezii Menggunakan Metode Budidaya Long Line Pada Kedalaman Berbeda Terhadap Peningkatan Berat Bibit: Kajian Pustaka. Jurnal Ilmu Kelautan Kepualauan. 3 (1), 46-58.

http://ejournal.unkhair.ac.id/index.php/kel autan.

Lutfiawan, M., Karnan \& Lalu, J. (2015). Analisis Pertumbuhan Sargassum sp. dengan Sistem Budidaya yang Berbeda di Teluk Ekas Lombok Timur Sebagai Bahan Pengayaan Mata Kuliah Ekologi Tumbuhan. Jurnal Biologi Tropis. 15(2), 135-144. ISSN: 1411-9587.

Nurjanah, N. Luthfiyana, T. Hidayat, M. Nurilmala and E. Anwar (2019). Utilization of seaweed porridge Sargassum sp. and Eucheuma cottonii as cosmetic in protecting skin. IOP Conf. Series: Earth and Environmental Science 278 (2019) 
012055 doi:10.1088/17551315/278/1/012055.

Muslimin \& Wiwin, K.P.S. (2017). Budidaya Rumput Laut Sargassum sp. dengan Metode Kantong Pada Beberapa Tingkat Kedalaman Di Dua Wilayah Perairan Berbeda. Jurnal Riset Akuakultur. 12(3). http://ejournal-balitbang.

kkp.go.id/index.php/jra.

Muslimin \& Wiwin, K.P.S. (2017). Petunjuk Teknis Budidaya Sargassum dengan Menggunakan Metode Lepas Dasar. Loka Penelitian dan Pengembangan Budidaya Rumput Laut. Desa Tabulo Selatan Boalemo. Gorontalo. ISBN: 978-60272533-4-6.

M. I. Fajri, I. Samidjan \& D. Rachmawati (2020). Pengaruh Jarak Tanam Rumput Laut (Sargassum sp.) Yang Berbeda Terhadap Pertumbuhan. Jurnal Sains Akuakultul Tropis. 4(2), 156-160. e-ISSN: 2621-0525.

Novianti, D.N., S. Rejeki, \& T. Susilowati. (2015). Pengaruh Bobot Awal Yang Berbeda Terhadap Pertumbuhan Rumput Laut Latoh (Caulerpa lentillifera) yang Dibudidayakan Didasar Tambak, Jepara. Jurnal of Aquaculture Management and Technology. $\quad 4(4): \quad 67-73$. https://ejournal3.undip.ac.id/index.php/ja mt/article/view/10048.

Rochmady, Sulaeman, \& La Salauddin (2017). Pengaruh Bobot Bibit Berbeda Terhadap Pertumbuhan Rumput Laut (Kappaphycus alvarezii) Strain Cokelat Metode Long Line Menggunakan Rumpun Ganda. Agrikan: Jurnal Agribisnis Perikanan. $\underline{8(2)}$, 1-7. https://doi.org/10.29239/j.agrikan.8.2.1-7.

Nico Runtuboy, N. \& Slamet, A. (2018). Optimalisasi Penyediaan Bibit Rumput Laut Kotonii (Kappaphycus alvarezii) Hasil Kultur Jaringan. Jurnal Penyuluhan Perikanan dan Kelautan. 12(1), 1-10. doi.org/10.33378/jppik.v12i1.96.
Sunu, D., Widyartini, A. I. Insan, \& Sulistyani (2015). Kandungan Alginat Sargassum polycystum pada Metode Budidaya dan Umur Tanam berbeda. Biosifera. 32(5).

Sahabati, S., Joppy, D. M., \& Lukas L.J.J.M. (2016). Pertumbuhan Rumput Laut (Kappaphycus alvarezii) Yang di Budidayakan Dalam Kantong Jaring Dengan Berat Awal Berbeda di Teluk Talengen Kepulauan Sangihe. Jurnal Budidaya Perairan. 4(3): 16-21. https://ejournal.unsrat.ac.id/index.php/bdp /article/view/14742/14311.

Saraswati, N.L.G.A., Yulius, Agustin, R., Hadiwijaya L., Salim, Aida, H., \& Eva, M. (2017). Kajian Kualitas Air Untuk Wisata Bahari di Pesisir Kecamatan Moyo Hilir dan Kecamatan Lape, Kabupaten Sumbawa. Jurnal Segara. 13(1), 37-47.

Sulystyaningsih, N.S., Rajuddin, S. \& Zainuddin (2019). Pengaruh Kedalaman dan Bobot Sargassum aquifolium Terhadap Tingkat Serangan Ice-Ice dan Kadar Karagenan Pada Rumput Laut Kappaphycus alvarezii. Jurnal Riset Akuakultur, 14 (1): 39-46.

Sidauruk SW, Sari, N.I, Diharmi, A., \& Arif I. (2021). Aktivitas antibakteri ekstrak Sargassum plagyophyllum terhadap bakteri Listeria monocytogenes dan Pseudomonas aeruginosa. Jurnal Pengolahan Hasil Perikanan Indonesia. 24 (1): 27-37. DOI: https://doi.org/10.17844/jphpi.v24i1 .33417 .

Yudasmara, G.A. (2014). Budidaya Anggur Laut (Caulerpa racemosa) Melalui Media Tanam Rigid Quadrant Nets Berbahan Bambu. Jurnal Sains dan Tekhnologi. 3(2). DOI: http://dx.doi.org/10.23887/jstundiksha.v3i2.4481.

Wila, L.H., N. Cokrowati \& Nanda, D. (2021). Pertumbuhan Rumput Laut Sargassum sp. Yang Dibudidayakan Pada Kedalaman Berbeda Di Teluk Ekas 
Lombok Timur. Jurnal Kelautan. 14(2): $185-191$ DOI: https://doi.org/10.21107/jk.v14i2.1 $\underline{0934}$.

Yusup, S., Ma'ruf, K., \& Abdul, M.B. (2017). Pengaruh Bobot Awal Yang Berbeda
Terhadap Pertumbuhan Dan Kandungan Keragenan Rumput Laut Kappaphycus alvarezii Yang Terserang Epifit dalam Rakit Jaring Apung. Jurnal Media Akuatika. 2(4) : 509-518. DOI: http://dx.doi.org/10.33772/jma.v2i4. 4356. 